\title{
CARACTERIZAÇÃO AMBIENTAL, HIDROGEOLÓGICA E GEOQUÍMICA DOS DEPÓSITOS ALUVIONARES DA BACIA HIDROGRÁFICA DO RIO PEQUENO - REGIÃO METROPOLITANA DE CURITIBA-PR

\author{
ANA LISETE ROCHA
}

\author{
DISSERTAÇÃO DE MESTRADO - Programa de Pós-Graduação em Geologia - UFPR \\ DATA DE DEFESA: 19/06/96
}

\begin{abstract}
Este trabalho apresenta os resultados dos estudos realizados em uma micro-bacia do rio Iguaçu, representada especificamente pela micro-bacia do rio pequeno, localizada no Município de São José dos Pinhais, na Região Metropolitana de Curitiba, visando a caracterização ambiental, hidrogeológica e geoquímica dos depósitos aluvionares desta com fins de abastecimento público. A existência de dados hidrogeológicos dos últimos 08 a 10 anos de coletas e sondagens, realizadas pela CPRM, indicando uma espessura considerável de aluviões na região, além do fato da Estação de Captação da SANEPAR estar situada no limite noroeste da bacia, foram fatores importantes na seleção da área objeto da pesquisa. Na citada microbacia, os depósitos aluvionares exibem uma extensão de cerca de $25 \mathrm{~km}$, enquanto que suas larguras variam entre 0,5 e $4 \mathrm{~km}$, nos trechos a montante e a jusante, respectivamente. Os aluviões são compostos por depósitos de areia e cascalhos mal-selecionados, intercalados por camadas de argila, assentando em discordância sobre o embasamento gnáissico-
\end{abstract}

migmatítico, com espessura máxima de 7 metros. A granulação varia de fina a grosseira, com estratificação horizontal a sub-horizontal. Na planície aluvionar de todo - Alto Iguaçu ocorrem atividades de extração de areias utilizadas para construção civil há cerca de 50 anos, sem nunca ter existido uma preocupação com a sua recuperação ambiental. As áreas lavradas, ou em processo de exploração, são similares entre sí, destacando-se na paisagem pela ocorrência de inúmeras cavas inundadas de água, com dimensões variáveis, separadas por estreitas ou largas faixas de terra. Existe um consenso da população que se instalou nesses locais, gerado pelo descaso institucional, de que estas áreas são como imensos depósitos de lixo. Os moradores contribuem para o entulhamento das cavas com lixo, acreditando que o terreno poderia se tornar mais "seco". Este estudo revelou que, apesar da degradação ambiental sofrida, as cavas, por suas características hidrogeológicas e geoquímicas, podem servir como um reservatório de água complementar ao abastecimento público da cidade de Curitiba. 